\title{
THE MAGNESIUM CONTENT OF THE ERYTHROCYTES IN PERNICIOUS AND SOME OTHER ANEMIAS
}

\author{
By OLE BANG AND SøREN L. ØRSKOV \\ (From Kommunehospitalet, Division III; Copenhagen, and Aarhus Universitet, Department \\ of Physiology; Aarhus, Denmark)
}

(Received for publication May 26, 1939)

The authors have previously reported (1) variations in the permeability of the red blood cells in pernicious anemia. In spite of the considerable rôle played by magnesium in important fields of biology, comparatively little study has been directed towards the magnesium content of the human red blood cells. Greenberg and Schmidt (2) state that magnesium is present in normal erythrocytes in quantities between 5.4 and $7.8 \mathrm{mgm}$. per cent, and that during anemia readings up to $15 \mathrm{mgm}$. per cent may be obtained.

Animal experiments carried out by Henriques and $\emptyset$ rskov (3) gave results suggesting that an increased magnesium content is a property of newly formed red cells. Anemia was induced in rabbits and dogs, either by bleeding or by injection of phenylhydrazine. During the regenerative stage, in which the young red blood cells are relatively more numerous, a considerable rise in erythrocyte magnesium was observed, occasionally after the bleeding, and regularly in the phenylhydrazine experiments.

This evidence seemed to warrant the probability that information regarding human anemic states might be obtained through investigations into the magnesium content of the erythrocytes, and the following study was undertaken.

\section{TECHNIQUE}

Five to $10 \mathrm{cc}$. of blood is collected by venepuncture and defibrinated by shaking with glass beads. A hematocrit reading is performed, and the red cells are separated from plasma by centrifugalization. The magnesium content is determined by the method of Cruess and Callaghan as modified by Henriques and $\emptyset$ rskov (3).

\section{Results}

The magnesium content of the erythrocytes was determined in 18 subjects whose blood findings were normal, 9 males and 9 females; the results are given in Table I. Values varying from 4.3 to $7.9 \mathrm{mgm}$. per cent were obtained, with an average
TABLE I

Normal subjects

(This group includes patients with various diseases as well as students, and so the heading "normal" covers the blood findings only.)

\begin{tabular}{|c|c|c|c|c|}
\hline Sex & Age & Hemoglobin & Erythrocytes & Magnesium \\
\hline $\begin{array}{l}\text { M. } \\
\text { M. } \\
\text { M. } \\
\text { M. } \\
\text { M. } \\
\text { M. } \\
\text { M. } \\
\text { M. } \\
\text { M. }\end{array}$ & $\begin{array}{c}\text { years } \\
8 \\
16 \\
18 \\
23 \\
24 \\
26 \\
33 \\
53 \\
58\end{array}$ & $\begin{array}{c}\text { per cent } \\
90 \\
100 \\
105 \\
95 \\
106 \\
98 \\
102 \\
95 \\
101\end{array}$ & $\begin{array}{c}\text { millions per } \\
\text { c. } \mathrm{mm} . \\
\mathbf{5 . 4} \\
5.0 \\
6.1 \\
5.4 \\
6.2 \\
5.2 \\
5.2 \\
5.1 \\
\mathbf{5 . 8}\end{array}$ & $\begin{array}{c}\text { mgm. } \\
\text { per cent } \\
5.3 \\
5.1 \\
5.9 \\
4.3 \\
4.9 \\
7.0 \\
7.2 \\
6.2 \\
4.8\end{array}$ \\
\hline $\begin{array}{l}\text { F. } \\
\text { F. } \\
\text { F. } \\
\text { F. } \\
\text { F. } \\
\text { F. } \\
\text { F. } \\
\text { F. } \\
\text { F. }\end{array}$ & $\begin{array}{l}21 \\
23 \\
24 \\
24 \\
29 \\
54 \\
58 \\
63 \\
71\end{array}$ & $\begin{array}{r}95 \\
100 \\
90 \\
91 \\
95 \\
101 \\
91 \\
99 \\
100\end{array}$ & $\begin{array}{l}5.0 \\
4.6 \\
4.9 \\
4.9 \\
5.1 \\
5.1 \\
5.5 \\
4.8 \\
5.2\end{array}$ & $\begin{array}{l}4.5 \\
6.7 \\
4.3 \\
4.9 \\
6.9 \\
7.9 \\
4.7 \\
6.4 \\
6.2\end{array}$ \\
\hline & & & \multicolumn{2}{|c|}{$\begin{array}{ll}\text { Minimum: } & 4.3 \\
\text { Maximum: } & 7.9 \\
\text { Average: } & 5.7\end{array}$} \\
\hline
\end{tabular}

of $5.7 \mathrm{mgm}$. per cent. These readings correspond fairly well with those given by Greenberg and Schmidt (2) and cited above.

Ten cases of anemia from various causes were studied; the readings obtained will be seen in $\mathrm{Ta}$ ble II. Among the 5 cases of anemia resulting from bleeding gastric ulcer, 2 presented values above normal, viz., Cases 1 and 2, while readings within the normal range were found in the remaining cases. Increased magnesium content was observed in a case of anemia following acute hemorrhage, Case 10, as well as in 1 case each of uremia and leukemia, and in 2 cases of anemia resulting from stomach carcinoma-in one of the latter cases the highest reading, $20.2 \mathrm{mgm}$. per cent, was found.

The findings in 8 cases of pernicious anemia are recorded in Table III. In these cases the diag- 
TABLE II

Anemia from various causes

\begin{tabular}{|c|c|c|c|c|c|}
\hline $\begin{array}{c}\text { Case } \\
\text { num- } \\
\text { ber }\end{array}$ & Cause of anemia & Date & $\begin{array}{l}\text { Hemo- } \\
\text { globin }\end{array}$ & $\begin{array}{l}\text { Eryth- } \\
\text { rocytes }\end{array}$ & $\begin{array}{l}\text { Mag- } \\
\text { ne- } \\
\text { dum }\end{array}$ \\
\hline & & & $\begin{array}{l}\text { per } \\
\text { cent }\end{array}$ & $\begin{array}{l}\text { millions } \\
\text { per } \\
\text { c. mam. }\end{array}$ & $\begin{array}{c}\text { meme } \\
\text { per } \\
\text { cent }\end{array}$ \\
\hline 1 & $\begin{array}{l}\text { Hematemesis in } \\
\text { peptic ulcer }\end{array}$ & $\begin{array}{l}\text { June } 8 \\
\text { June } 9\end{array}$ & $\begin{array}{l}59 \\
51\end{array}$ & $\begin{array}{l}2.7 \\
2.4\end{array}$ & $\begin{array}{l}9.3 \\
9.1\end{array}$ \\
\hline 2 & $\begin{array}{l}\text { Hematemesis in } \\
\text { peptic ulcer }\end{array}$ & $\begin{array}{l}\text { January } 14 \\
\text { February } 14\end{array}$ & $\begin{array}{l}38 \\
87\end{array}$ & & $\begin{array}{r}10.0 \\
5.8\end{array}$ \\
\hline 3 & $\begin{array}{l}\text { Hematemesis in } \\
\text { peptic ulcer }\end{array}$ & $\begin{array}{l}\text { April } 23 \\
\text { May } 4 \\
\text { May } 10\end{array}$ & $\begin{array}{l}41 \\
45 \\
46\end{array}$ & $\begin{array}{l}2.4 \\
2.7 \\
2.9\end{array}$ & $\begin{array}{l}4.1 \\
7.5 \\
4.1\end{array}$ \\
\hline 4 & $\begin{array}{l}\text { Melena in peptic } \\
\text { ulcer }\end{array}$ & $\begin{array}{l}\text { April } 21 \\
\text { May } 17\end{array}$ & $\begin{array}{l}38 \\
78\end{array}$ & $\begin{array}{l}2.1 \\
4.8\end{array}$ & $\begin{array}{l}6.3 \\
5.3\end{array}$ \\
\hline 5 & $\begin{array}{l}\text { Melena in peptic } \\
\text { ulcer }\end{array}$ & $\begin{array}{l}\text { May } 27 \\
\text { May } 30\end{array}$ & $\begin{array}{l}46 \\
50\end{array}$ & $\begin{array}{l}2.2 \\
2.9\end{array}$ & $\begin{array}{l}6.5 \\
7.4\end{array}$ \\
\hline 6 & Uremia & $\begin{array}{l}\text { May } 23 \\
\text { June } 7\end{array}$ & $\begin{array}{l}65 \\
58\end{array}$ & $\begin{array}{l}3.2 \\
3.0\end{array}$ & $\begin{array}{r}6.3 \\
11.9\end{array}$ \\
\hline 7 & Leukemia* & & 17 & 0.7 & 15.5 \\
\hline 8 & $\begin{array}{l}\text { Carcinoma of } \\
\text { stomach }\end{array}$ & & 34 & 2.7 & 20.2 \\
\hline 9 & $\begin{array}{l}\text { Carcinoma of } \\
\text { stomach }\end{array}$ & & 49 & 2.5 & 10.2 \\
\hline 10 & $\begin{array}{l}\text { Operation with } \\
\text { blood loss }\end{array}$ & & 30 & 2.0 & 14.6 \\
\hline
\end{tabular}

* Leukocytes not thoroughly removed from the layer of red cells may constitute a cause of error.

nosis was established by the hematological examination. In all but one (Case 6) there was an adequate response to liver treatment. In Case 6 the postmortem examination, including bone marrow microscopy, confirmed the diagnosis, while no other morbid state was revealed.

It will be noted that in 7 out of these 8 cases of pernicious anemia (Cases 1 to 7) the erythrocytes contained magnesium in quantities above normal, so far as the untreated stage is concerned. In 6 of the cases mentioned (Cases 1 to 6 ), the magnesium values decreased following liver treatment, while in 1 case (Case 7) no such change was seen.

The values obtained in Case 8 differ markedly from the findings established in the other cases. The magnesium content of the erythrocytes is exceedingly low, even below the normal limit, and no change is observed during treatment. As stated above, the course of the disease and the response to liver treatment seemed to exclude other possi-
TABLE III

Pernicious anemia

\begin{tabular}{|c|c|c|c|c|c|c|}
\hline $\begin{array}{l}\text { Case } \\
\text { num- } \\
\text { ber }\end{array}$ & Age & Sex & Date* & $\begin{array}{l}\text { Hemo- } \\
\text { globin }\end{array}$ & $\begin{array}{c}\text { Erythro- } \\
\text { cytes }\end{array}$ & $\begin{array}{c}\text { Mag- } \\
\text { nesium }\end{array}$ \\
\hline 1 & $\begin{array}{c}\text { years } \\
75\end{array}$ & M. & $\begin{array}{l}\text { October } 7 \\
\text { October } 7 . . . \\
\text { October } 18\end{array}$ & $\begin{array}{c}\text { per cent } \\
30 \\
0 \\
47\end{array}$ & $\begin{array}{c}\text { millions } \\
\text { per } \\
\text { c. mm. } \\
0.9 \\
1.7\end{array}$ & $\begin{array}{c}\text { mgm. } \\
\text { per cent } \\
14.2 \\
5.4\end{array}$ \\
\hline 2 & 53 & M. & $\begin{array}{l}\text { April } 12 \\
\text { April 14 } \\
\text { April 15 } \\
\text { April } 24\end{array}$ & $\begin{array}{c}37 \\
36 \\
53\end{array}$ & \begin{tabular}{c}
1.2 \\
\hdashline$\ldots$ \\
1.3 \\
2.5
\end{tabular} & $\begin{array}{c}15.3 \\
12.9 \\
7.8\end{array}$ \\
\hline 3 & 74 & M. & $\begin{array}{lr}\text { February } & 2 \\
\text { February } & 3- \\
\text { February } & 25\end{array}$ & $\begin{array}{c}45 \\
57\end{array}$ & $\begin{array}{c}1.5 \\
2.5\end{array}$ & $\begin{array}{c}13.0 \\
4.6\end{array}$ \\
\hline 4 & 75 & F. & $\begin{array}{l}\text { April } 7 \\
\text { April } 8 \\
\text { April 13 } \\
\text { April 24 }\end{array}$ & \begin{tabular}{c}
64 \\
62 \\
\hdashline 72
\end{tabular} & \begin{tabular}{c}
2.1 \\
2.0 \\
\hdashline 2.6
\end{tabular} & \begin{tabular}{c}
10.4 \\
11.2 \\
\hdashline 8.6
\end{tabular} \\
\hline 5 & 70 & F. & $\begin{array}{lr}\text { January } & 30 \\
\text { February } & 3 \\
\text { February } & 17\end{array}$ & \begin{tabular}{c}
63 \\
\hdashline 68
\end{tabular} & $\begin{array}{c}2.6 \\
3.3\end{array}$ & $\begin{array}{c}10.1 \\
8.1\end{array}$ \\
\hline 6 & 68 & F. & March $10 \dagger$ & 16 & 0.7 & 14.3 \\
\hline 7 & 57 & F. & $\begin{array}{l}\text { April 7 } \\
\text { April 8 } \\
\text { April 13 } \\
\text { April 24 }\end{array}$ & $\begin{array}{c}59 \\
59 \\
-71\end{array}$ & \begin{tabular}{c}
1.9 \\
1.9 \\
\hdashline 3.0
\end{tabular} & $\begin{array}{c}8.6 \\
9.4 \\
8.5\end{array}$ \\
\hline 8 & 80 & F. & $\begin{array}{l}\text { November } 19 \\
\text { November } 20 \\
\text { January } 10\end{array}$ & $\begin{array}{c}36 \\
81\end{array}$ & \begin{tabular}{c}
1.4 \\
\hdashline 3.4
\end{tabular} & $\begin{array}{c}3.8 \\
3.5\end{array}$ \\
\hline
\end{tabular}

....... indicates the beginning of treatment.

$\dagger$ Died soon after admission.

bilities than pernicious anemia, and no apparent signs of complications were noted. In the erythrocytes from this case a very low content of potassium was also found, viz., 125 to $152 \mathrm{mgm}$. per cent. A few examinations subsequently carried out indicated a gradual return to normal values. After 9 months, $6.4 \mathrm{mgm}$. per cent of magnesium, and $396 \mathrm{mgm}$. per cent of potassium were observed. Possibly a transitory " demineralization," not directly depending on the pernicious anemia, is the explanation in this instance.

\section{Comment}

It seems as though an increased magnesium content of the erythrocytes is occasionally but not regularly associated with anemia resulting from relatively acute blood loss. In anemias of longer 
standing, an increased magnesium content may be encountered more frequently.

In the anemias resulting from hemorrhage, as well as in the experimental anemias of the same origin, the conception of a relative preponderance of young cells seems a justifiable interpretation in those cases where an increased magnesium content is found.

In the other anemias examined (in uremia, leukemia, and stomach carcinoma), blood loss through bleeding is not the chief cause; on the contrary, a toxic inhibition of the hematopoietic function of the bone marrow is widely accepted as the dominating cause in such cases. We may assume that small portions of the marrow, still capable of producing blood cells, must counterbalance so far as possible the prevailing blood destruction. It seems, however, improbable that blood destruction should be going on at the normal rate. We feel that, in the circumstances prevailing, blood cells with less than the normal lifetime may occur, and so the amount of blood cells which is at any moment available for destruction may be relatively increased; further, the toxic agents supposedly acting on the bone marrow may influence as well the circulating cells.

It will be seen that the consequence of such a relatively increased destruction is a condition comparable to diseases in which increased hemolysis is the primary factor; in either case the bone marrow (or what may remain of it) must increase the rate of production, and in either case the young cells predominate in the red cell population. The mechanism outlined would account for the finding of erythrocytes with a high magnesium content.

What is said above has to some extent a bearing on pernicious anemia also. Though for the moment a marrow inhibition, the " maturation arrest," is held responsible for the development of anemia in this condition, the signs of increased blood destruction remain to be adequately accounted for. The hypothesis of accumulation of hemoglobin derived pigment (and of iron) resulting from nonutilization is not based upon sound and tenable physiological principles. Further, the picture presented by the bone marrow during relapse is, to the unprejudiced observer, that of intensified activity; immature cells and numerous mitoses characterizing the widely expanded red marrow.
Further still, when remission occurs, the signs of increased activity decrease rapidly, and in a few days the marrow regains almost normal appearance; the "pernicious" character of the bone marrow is almost lost even before any rise in peripheral blood value is conspicuous. We adhere, therefore, to the formerly accepted view, and regard pernicious anemia as a condition resulting from increased blood destruction. This increased destruction, presumably, is brought about by an abnormal fragility and accordingly a short lifetime of the red cells (in the bone marrow as well as in the blood stream). The bone marrow findings during relapse are regarded as representing the utmost effort of the hematopoietic system in an endeavor to counterbalance the premature destruction of its shortlived products. As soon as active "liver principle" is available to the marrow, cells with a normal lifetime can be produced, i.e., the organism is no longer "pernicious." This means that the hematopoietic activity may be reduced to a level corresponding to the "normal" response to the prevailing blood deficit. The remission occurs, not as a consequence of increased activity, but as the result of a stabilization of the product. The time interval between the beginning of liver treatment and the first signs of peripheral blood increase must be looked upon as representing the time needed to replace defective cells by normal ones. We have found a support for this conception in the fact, previously reported, that the permeability of the erythrocytes is abnormally increased in pernicious anemia during relapse, while this phenomenon disappears in the course of a few days following liver treatment. We may say that the defective "pernicious" red cells vanish and are replaced by " normal" cells (i.e., cells with a normal permeability and a normal lifetime).

The increased magnesium content of the "pernicious " red cells found during relapse in the majority of the cases of pernicious anemia examined, as well as the relative decrease in magnesium content frequently following treatment, is in keeping with the view proposed, so far as a high magnesium content is characteristic of a young blood cell.

Further investigations are needed for the evaluation of these interpretations, but we feel confident that the introduction of magnesium studies 
into the field of hematology will prove to be helpful in solving some of the problems outlined.

\section{Summary}

An increased magnesium content of the red blood cells is often, but not always, found in anemias from various causes, probably indicating a relative preponderance of young cells. In pernicious anemia, high magnesium values are found during relapse in the majority of the cases examined, while a decrease towards normal values takes place during remission. These findings support the view that a short lifetime of the red cells, with a concomitantly increased rate of destruction, is a decisive factor in the development of the pernicious anemia.

\section{BIBLIOGRAPHY}

1. Bang, O., and Ørskov, S. L., Variations in the permeability of the red blood cells in man, with particular reference to the conditions obtaining in pernicious anemia. J. Clin. Invest., 1937, 16, 279.

2. Greenberg, D. M., and Schmidt, C. L. A., Occurrence, transport and regulation of calcium, magnesium and phosphorus in the animal organism. Physiol. Rev., 1935, 15, 297.

3. Henriques, V., and Ørskov, S. L., Untersuchungen über den Magnesium- und den Kaliumgehalt der roten Blutkörperchen bei Anämie. Skandinav. Arch. f. Physiol., 1939, 82, 86. 